\title{
Depression and Repetitive Negative Thinking among Older Adults: The Specific Role of Executive Dysfunction
}

\section{Yaşlılarda Depresyon ve Tekrarlayan Olumsuz Düşünce: Yürütücü İşlev Bozukluğunun Özgün Rolü}

\author{
Yasemin Sohtorik İlkmen ${ }^{1}\left(\right.$, , Ayşe Altan-Atalay ${ }^{2}$ (i)
}

Note: This research did not receive any specific grant from funding agencies in the public, or not-for-profit sector.

'Dr. Lecturer, Boğaziçi University, Department of Psychology, Istanbul, Turkey ${ }^{2}$ Dr. Lecturer, Koç University, Faculty of Arts and Sciences, Department of Psychology, Sarıyer, Istanbul, Turkey

ORCID: Y.S.I. 0000-0002-9479-4942; A.A.A. $0000-0001-9748-2517$

Corresponding author/Sorumlu yazar: Yasemin Sohtorik Ilkmen, Boğaziçi University, Department of Psychology, Istanbul, Turkey

E-mail/E-posta: sohtorik@boun.edu.tr

Submitted/Başvuru: 01.10.2019 Revision Requested/Revizyon Talebi: 03.10.2020

Last Revision Received/Son Revizyon:

16.06.2020

Accepted/Kabul: 19.06 .2020

Citation/Atıf: Sohtorik Ilkmen, Y., \& Altan-Atalay, A. (2020). Depression and repetitive negative thinking among older adults: The specific role of executive dysfunction. Psikoloji Çalışmaları - Studies in Psychology, 40(2): 561-578. https://doi.org/10.26650/SP2019-0074

\begin{abstract}
Depression in older adults poses serious consequences, thus understanding vulnerability factors may contribute to the development and implementation of appropriate clinical interventions. Executive function deficits have been proposed as risk factors for geriatric depression. One possible factor that may facilitate the impact of executive function deficits is Repetitive Negative Thinking (RNT) patterns that had been defined as an inclination to entertain uncontrollable, abstract, repetitive, and mainly negative thoughts about events that took place in the past or will take place in the future. The present study aimed to test the moderator roles of different dimensions of executive function on the relationship between repetitive negative thinking and geriatric depression. A sample of 128 community-dwelling older adults ( 63 women, 65 men), between 60 and 82 years of age, were administered both self-report questionnaires measuring depression (Geriatric Depression Scale), and repetitive negative thinking (Penn State Worry Questionnaire) and neuropsychological tests measuring inhibition (Stroop ColorWord Test) and working memory (Digit Span Backward). All participants lived independently in Istanbul, and spoke Turkish as their native language. The results showed that working memory capacity significantly moderated the relationship between repetitive negative thinking and depression as predicted. However, the results did not indicate the same moderator effect of inhibition. The present data suggests that high working memory capacity is able to moderate the relationship between repetitive negative thinking and depression among older adults. This finding has important implications for clinical interventions targeting depression in older adults whose clinical presentations are complicated with repetitive negative thinking and executive dysfunction.
\end{abstract}

Keywords: Geriatric depression, repetitive negative thinking, executive function, working memory, worry 


\section{ÖZ}

Yaşlılarda depresyon ciddi sonuçlara sebebiyet vermektedir, bu yüzden depresyona hassasiyet yaratan faktörleri anlamak, gerekli terapi yöntemlerinin geliştirilmesinde ve uygulanmasında faydalı olacaktır. Yaşlılıkta depresyona sebep olan risk faktörlerinden birisi yürütücü işlev bozukluklarıdır. Yürütücü işlevler üzerinde olumsuz etkisi olabilecek bir faktör geçmişte olmuş veya gelecekte olabilecek olaylara ilişkin kontrol edilemez, soyut, tekrarlayan ve genelde olumsuzluk içeren düşünme eğilimi olarak tanımlanan tekrarlayan olumsuz düşünce şeklidir. Bu araştırmanın amacı farklı yürütücü işlevlerin geriyatrik depresyon ve tekrarlayan olumsuz düşünce arasındaki ilişkide biçimlendirici etkisini araştırmaktır. Araştırmanın örneklemini 60-82 yaşları arasında 128 (63 kadın, 65 erkek) bağımsız yaşayan katılımcı oluşturmaktadır. Katılımcılara depresyon (Geriatrik Depresyon Ölçeği) ve tekrar eden düşünce eğilimini ölçen (Penn State Endişe Ölçeği) özbildirim ölçekleri ile inhibisyon (Stroop Renk-Kelime Testi) ve işler bellek kapasitesini ölçen (Sayı Dizisi Tersten) nöropsikolojik testler uygulanmıştır. Katılımcıların tamamı İstanbul'da ikamet etmektedir ve anadillerini Türkçe olarak belirtmişlerdir. Analizler, işler bellek kapasitesinin depresyon ve tekrarlayan olumsuz düşünce arasındaki ilişkiyi biçimlendirdiğini göstermiştir. Sonuçlara göre, düşük düzeyde tekrarlayan olumsuz düşünce gösteren katılımcılarda, işler bellek kapasitesinin depresyon üzerinde bir etkisi olmadığı bulunmuştur. Buna karşın, yüksek düzeyde tekrarlayan olumsuz düşünce gösteren yaşlılarda işler bellek kapasitesinin yüksek olması tekrarlayan olumsuz düşüncelerin olumsuz etkilerini yumuşattığı ve düşük depresyon puanları ile ilişkili olduğu belirlenmiştir. Ancak aynı biçimlendirici etki inhibisyon için bulunamamıştır. Elde edilen bulgular yaşl1lıkta yüksek işler bellek kapasitesinin, depresyon ve tekrarlayan olumsuz düşünce arasındaki ilişkide tampon görevi üstlendiğini göstermiştir. Bu çalışmanın tekrarlayan olumsuz düşünce ve yütürücü işlev bozukluğunun da etkisiyle daha komplike bir hal alan geriyatrik depresyonun tedavisinde önemli bir yol gösterici olduğu düşünülmektedir.

Anahtar Kelimeler: Geriyatrik depresyon, tekrarlayan olumsuz düşünce, yürütücü işlevler, işler bellek, endişe 
Geriatric depression, which is becoming an increasingly common condition (Luppa et al., 2012), is associated with decreased quality of life (Doraiswamy, Khan, Donahue, \& Richard, 2002) and a major risk factor for suicide (Alexopoulos, Bruce, \& Hull, 1999; Conwell, Duberstein, \& Caine, 2002). There is ample evidence that depression in older adults presents differently from depression in younger adults (Alexopoulos et al., 2002). Specifically, compared with younger people, older adults report problems such as difficulty sleeping, tiredness, slowness in psychomotor functioning, loss of interest in living, and feelings of hopelessness about future as well as cognitive complaints such as memory problems, cognitive decline and executive dysfunction quite frequently (Fiske, Wetherell, \& Gatz, 2009). These unique characteristics including high prevalence of cognitive and somatic complaints among older adults, contributed to the development of different assessment instruments to measure depression in geriatric populations (Yesavage et al., 1983). Investigators have been trying to identify vulnerability factors for geriatric depression including neuropsychological markers such as executive function, indicating that executive dysfunction may be associated with chronicity of depression in geriatric populations (Kalayam \& Alexopoulos, 1999) as well as greater chance of relapse and recurrence (Alexopoulos et al., 2000).

The objective of this study was to investigate the role of executive dysfunction as a possible moderator variable in the relationship between geriatric depression and epetitive negative thinking. Understanding executive function difficulties and mechanisms that explain their impact on depression symptoms among elderly individuals is particularly essential to design and deliver appropriate treatments. Research showed that elderly individuals who were prescribed anti-depression medication showed poor treatment results if they also exhibited executive dysfunction (Alexopoulos et al., 2005). The role of repetitive negative thinking on depression was well established (Nolen-Hoeksema, 2000), however, there are very few studies which examined the moderator role of executive dysfunction on the relationship between depression and repetitive negative thinking, particularly among elderly individuals. Given the unique characteristics and challenges of depression in older ages, the current study aims to contribute to this emerging literature.

\section{Executive Dysfunction, Negative Ruminative Thinking, and Depression}

Executive function (EF) is an umbrella term that refers to a set of capacities that underlie an individual's ability to keep relevant information in mind, shift between different types of processes, tasks or information depending on the situational 
requirements, in addition to planning and goal directed behavior. Miyake et al. (2000) suggested a widely accepted model of EF that involves independent but yet still related dimensions of shifting, updating, and inhibition. Shifting refers to the ability to shift one's attention between different tasks. This ability involves multiple functions including the ability to engage in and disengage from tasks based on the changed demands and perform new tasks in the face of interference. Updating on the other hand refers to the ability to maintain task relevant information in working memory (WM), monitor the relevance of new information and update old information accordingly (Miyake et al., 2000). Lastly, inhibition is the capacity that allows the individual to deliberately suppress the dominant automatic and prepotent responses (Miyake et al., 2000). Inhibition capacity is suggested to be the core EF capacity that gives way to the other capacities through the course of development (Diamond, 2013; Friedman \& Miyake, 2017). Moreover, there is evidence indicating that performance on different components of executive function decline with age (Gazzaley, Cooney, Rissman, \& D'Espesito, 2005; Hasher, Quig, \& May, 1997; West \& Alain, 2000;). For instance, in one study researchers postulated that older adults experience difficulty suppressing irrelevant information in their WM, thus lowering its capacity and efficiency (Hasher et al., 1997). In line with that, Gathercole (1994) also reported a significant age-related decline in WM capacity.

EF deficits have been documented as risk factors that are associated with a vulnerability to psychological disorders, including depression (Joorman \& Gotlib, 2010; Snyder, 2013). According to Joorman and Gotlib (2010), deficits in the WM capacity is associated with a failure in keeping the irrelevant/dysfunctional information while the processing of incoming information serves as a factor that makes individuals more susceptible to depression. This view was also supported by Hubbard, Hutchison, Hambrick, and Rypma (2016) who found that depressed individuals performed worse on WM tasks when they were exposed to depressive information. Snyder (2013) in a meta-analysis and review also indicated that major depressive disorder was associated with impaired performance on all domains of EF.

Findings from both clinically depressed and subclinical populations led researchers to examine similar connections between EF and depressed mood in older adults hypothesizing that age related executive dysfunction may particularly predispose geriatric populations to experience depression (Lockwood, Alexopoulos, \& van Gorp, 2002; Nebes et al., 2000). For example, Lockwood et al. (2002) found that compared to depressed younger adults 
and healthy older adults, depressed older adults performed poorly on the measures of selective attention and inhibitory control. Based on such findings, Alexopoulos (2003) proposed a depression-executive dysfunction syndrome hypothesis to explain late-onset depression associated with impaired executive function. Similarly, Nebes et al. (2000) in their study with depressed and non-depressed individuals from a geriatric population revealed significant WM related differences between two groups. Likewise, von Hippel, Vasey, Gonda, and Stern (2008) focused on inhibition and reported an association between late-onset depression and executive deficit, suggesting that executive dysfunction may be responsible for depressive symptoms as a function of ineffective inhibitory control over negative and ruminative thoughts. It was suggested that age-related executive function deficits might be synergistically interacting with other cognitive risk factors for depression and thus result in elevations in the severity of depressive symptoms.

A review of the previous studies on the connection between EF and depression, however, highlights the unequivocal findings regarding this relationship especially in geriatric populations (Fischer et al., 2008). Specifically, the results of a recent metaanalytic study on depression and EF suggested that older patients with major depressive disorder did not differ in their performance on any measures of executive function as compared with non-depressed older participants (Snyder, 2013). Such inconsistent findings regarding the association between $\mathrm{EF}$ and depression may emerge from several factors. First, the way the EF capacity is measured may be a significant factor responsible for varying results due to the multi componential nature of EF. Secondly, other risk factors that interact with impaired EF impacting the severity of depressive symptoms may account for the inconsistencies (Snyder, 2013).

One possible factor that may facilitate the impact of executive function deficits is Repetitive Negative Thinking (RNT) patterns that had been defined as an inclination to entertain uncontrollable, abstract, repetitive, and mainly negative thoughts about the events that took place in the past or will take place in the future (Ehring \& Watkins, 2008). RNT had been proposed as a transdiagnostic factor that has significant associations with various conditions such as depression, anxiety, insomnia, and eating disorders (Ehring \& Watkins, 2008; Samtani \& Moulds, 2017). RNT patterns escalate an individual's vulnerability for psychopathology by increasing focus on negative aspects of life. This tendency, though begins with the aim of making a meaning out of life experiences and coping with difficult situations, may soon turn into a maladaptive pattern especially when 
the individual experiences deficits in terminating the repetitive thinking episodes. Failing to control RNT, augments the impact of the negative content which in turn contributes to the worsening of both depressive and anxiety symptoms (Watkins, 2016). A majority of the past research focused on both worry and rumination as vulnerability factors for mood disorders (Nolen-Hoeksema, 2000; Watkins, 2016). Although rumination had frequently been suggested as the type of RNT that is specifically associated with mood disorders (Nolen-Hoeksema, 2000), empirical evidence suggesting elevated levels of worry to be significantly associated with depression (Buck, Kelly, \& Silver, 2008; Segerstrom, Tsao, Alden, \& Craske, 2000) also exists. Studies consistently indicate that elevated levels of RNT (in the form of either worry or rumination) predicted both depressive disorder and subclinical depressive symptoms (Joormann \& Gotlib, 2010).

Recently there has been an increase in the number of studies on the association between RNT and EF capacities focusing on the possible implications of this relationship in mental health outcomes. For example, Pe, Raes, and Kuppens (2013) reported that superior WM capacity can impede the negative impact of RNT (in the form of rumination) on intensity of negative affect. Some researchers consider poor EF capacity as the factor that lies at the core of the problem and suggest that depressive symptoms emerge due to low levels of attentional control over RNT (Koster, De Lissnyder, Derakshan, \& De Raedt, 2011). Similarly, according to Joormann et al. (2007), regulation of negative affect or RNT and whether it will lead to more severe levels of depression depends on the efficient use of cognitive control capacities. Despite the abundance of studies indicating both EF deficits and RNT as interacting factors contributing to the severity and persistence of depressive symptoms in younger adults, the same relationship was examined in the geriatric populations by only a few studies (Philoppot \& Agrigoroaei, 2017; von Hippel et al. 2008). However, there is a need for further investigation in this area due to the unique characteristics of geriatric depression.

The present study was designed to investigate the relationship between RNT and depression among participants over age 60, and how different components of executive function (e.g., inhibitory control and WM) impact this relationship. The current study predicts that the association between worry (as a subtype of RNT, which is accepted as an indicator of RNT intensity in the current study) with geriatric depression will change depending on the levels of the individual's inhibitory control and WM capacity. In other words, it was hypothesized that: 
H1: For individuals who are not prone to experiencing RNT, good or poor EF skills (inhibition and/or WM) will not be associated with the levels of depression.

H2: For individuals who are prone to experiencing negative thoughts in a repetitive way, the high level of EF will moderate the negative impact of RNT, and thus will be associated with less severe levels of geriatric depression.

\section{METHOD}

\section{Participants}

The participants were 128 (63 women, 65 men) non-clinical community dwelling older adults (between the ages of 60 and 82) fluent in Turkish. They were recruited through personal contacts, and all were living independently in Istanbul. Participants were selected based on several criteria. All participants were able to read and write. They scored 24 and higher on the Turkish Mini Mental Status Exam (Güngen, Ertan, Eker, Yaşar, \& Engin, 2002); for participants with 5 years or less of formal education, Mini Mental Status Exam (MMSE) for uneducated was used with same cut off (Ertan et al., 1999). No participant had prior history of neurological (e.g., stroke, dementia, head trauma, seizure disorder) or psychiatric disorders (e.g., schizophrenia, bipolar disorder, sleep disorders, substance use disorders). Participants who were on medications that could affect cognitive functioning were excluded. No participants had a history of alcohol or substance abuse, and had not used any recreational drugs or alcohol in the past 12 hours. Furthermore, participants with color blindness or visual impairments were excluded from the study. If participants used glasses for reading, they were required to wear it throughout the research session. Demographics and descriptive statistics of the participants are provided in Table 1.

Table 1. Descriptive Statistics of the Study Variables by Gender

\begin{tabular}{lcccccc}
\hline & \multicolumn{2}{c}{ Female } & \multicolumn{5}{c}{ Male } \\
\hline Variables & $\boldsymbol{M}$ & $\boldsymbol{S D}$ & $\boldsymbol{N}$ & $\boldsymbol{M}$ & $\boldsymbol{S D}$ & $\boldsymbol{N}$ \\
\hline MMSE & 27.3 & 1.62 & 63 & 27.2 & 1.65 & 65 \\
Age & 69 & 5.67 & 63 & 68 & 5.81 & 65 \\
Education & 9.9 & 4.55 & 63 & 11.2 & 5.25 & 65 \\
Stroop-Int & -4.3 & 7.02 & 63 & -5.9 & 9.46 & 65 \\
DS-B & 4.8 & 2.01 & 63 & 5 & 1.97 & 65 \\
PSWQ & 45.5 & 12.93 & 63 & 38.3 & 11.38 & 65 \\
GDS & 7.8 & 5.69 & 63 & 6 & 4.26 & 65 \\
\hline
\end{tabular}

Note. MMSE = Mini Mental Status Exam; Stroop-Int = Stroop Interference Score; DB-B = Digit Span Backward; PSWQ = Penn State Worry Questionnaire; GDS = Geriatric Depression Scale. 


\section{Measures}

Stroop Color-Word Test (SCWT). The SCWT (Golden, 1978) is a test that assesses the ability to inhibit one's automatic response when there are two competing stimuli waiting to be processed, in this case reading words and naming colors. Originally proposed by Stroop (1935), the test allows for the calculation of an interference score, also known as Stroop effect. The SCWT is composed of 3 parts (two congruent and one incongruent conditions). The first task shows name of colors (red, blue, green) printed randomly in black ink on a white A4 size paper in five by 20 matrix of words (total of 100 words). Participants are asked to read them as fast as they can in a 45-secondperiod, starting with the congruent condition. The second task displays "XXXX" printed in the three colors mentioned above, and participants have to name the colors as quickly as they can in 45 seconds, second congruent condition. In the last task, the incongruous condition, there are names of the colors (red, blue, green) printed in incongruent colors of ink, and participants are asked to name the colors as fast as they can. In this task participants are required to inhibit reading the words, presumably a prepotent response. Instead they are supposed to name the color of the ink, which is assumed to be a more effortful task. Total scores are calculated by counting the correct number of items (Word [W], Color [C], and Color-Word [CW]) stated by the participants in 45 seconds. An interference score is then calculated using the following formula: CW- ((W x C) / (W+ C)) (Golden, 1978). This calculation yields scores that range from positive to negative. Positive scores indicate intact or better ability to inhibit interference, while negative scores reflect impaired ability to inhibit. The SCWT was translated to Turkish by Bogazici University Neuropsychology Lab staff ${ }^{1}$ (graduate students) under the supervision and review of practicing neuropsychologists.

Digit Span Backward (DS-B). DS-B from the Wechsler Adult Intelligence ScaleRevised (Wechsler, 1981) was used as a measure of WM. In this task, participants were verbally presented digits with increasing length and asked to repeat the digits in reverse order. DS-B starts with 2 digits (longest 9 digits) and is presented with approximately one second interval between each digit. The test was discontinued after two consecutive failures of the same digit length. The score was the total number of correct trials. The task was adapted into Turkish by Sezgin, Baştuğ, Yargıı-Karaağaç, \& Yılmaz, 2014.

1 The first author was involved in the translation of this version of the SCWT. This Turkish translation of the test was not published; further information can be requested from the first author. 
Geriatric Depression Scale (GDS). GDS is a self-report measure of depressive symptoms designed to be used with geriatric populations (Yesavage et al., 1983). There are 30 items answered as yes or no with possible scores ranging from 0 to 30 (answers indicating depression are given a score of 1 and answers indicating no depression are given a score of 0). It was adapted to Turkish by Ertan, Eker and Şar in 1997 with good psychometric support. In a more recent reliable and valid study of the scale with Turkish elderly, test-retest reliability (one-week interval) was noted to be reasonable $(r=0.74)$ with a high level of internal consistency $(\alpha=.91)$ (Ertan \& Eker, 2000).

Penn State Worry Questionnaire (PSWQ). PSWQ is a self-report 5-point Likert type scale with 16 questions measuring excessive and uncontrollable anxiety (Meyer, Miller, Metzger, \& Borkovec, 1990). The psychometric properties of the scale for older adults are satisfactory with adequate internal consistency, strong convergent validity and good test-retest reliability for both non-clinical and clinical samples (Wuthrich, Johnco, \& Knight, 2014). Turkish adaptation, reliability and validity study of the scale was conducted by Y1lmaz, Gençöz, and Wells (2008). The researchers suggest that PSWQ Turkish version is a reliable $(\alpha=.91)$ and valid measure of pathological worry in Turkish society. In the present study PSWQ is used to assess the intensity of RNT.

\section{Procedure}

The study was conducted after receiving Ethics Committee approval at Yeditepe University. Each participant was tested individually after they signed the informed consent form. All instruments were given in the same fixed order by advanced psychology undergraduate students trained to administer all measures by the first author. Participants did not receive compensation for their participation in this study.

\section{Data Analysis}

Descriptive characteristics were examined with SPSS and to test the interactive effect of RNT with WM and inhibition, AMOS 24.0 (Byrne, 2016) which utilizes the Maximum Likelihood Estimation (MLE) was used. Both the direct and interaction effects were estimated through calculation of bias-corrected $95 \%$ confidence intervals (CIs). Model fit was evaluated based on the criteria set by Bentler (1990), Hu and Bentler (1999), Hu, Bentler and Kano (1992) and Kline (1998) which are a CMIN/DF ratio below 3, Comparative Fit Index above .95 (coefficients above .90 are also considered as signs of acceptable fit), and Root-mean- square error of approximation 
(RMSEA) coefficient below .05 (RMSEA coefficient below .08 are also considered as indicators of good fit). Finally, further probing of the significant interactions were performed with the SPSS macro PROCESS (Hayes, 2013).

\section{RESULTS}

Descriptive statistics and Pearson's correlation coefficients for all study variables are presented in Table 1 and 2, respectively. Results revealed significant correlations between worry and depression. However, the correlations of Stroop interference and DS-B with depression and worry were non-significant.

Table 2. Means, Standard Deviations, Internal Consistency Reliability Coefficients, and Pearson's Correlations for the Study Variables

\begin{tabular}{|c|c|c|c|c|c|c|c|c|c|}
\hline & $M$ & $S D$ & 1 & 2 & 3 & 4 & 5 & 6 & $\alpha$ \\
\hline 1. PSWQ & 41.8 & 12.66 & & & & & & & .85 \\
\hline 2. GDS & 6.9 & 5.08 & $.60 * *$ & & & & & & .79 \\
\hline 3. Stroop & -5.1 & 8.36 & .00 & .03 & & & & & \\
\hline 4. DS-B & 4.9 & 1.99 & -.01 & -.14 & $.24 * *$ & & & & \\
\hline 5. Gender & & & $-.29 * *$ & $-.18^{*}$ & -.09 & .05 & & & \\
\hline 6. Age & 68.5 & 5.74 & -.08 & -.05 & -.08 & $-.29 * *$ & -.09 & & \\
\hline 7.Education & 10.5 & 4.94 & -.10 & $-.21^{*}$ & .03 & $.47 * *$ & .14 & $-.19 *$ & \\
\hline
\end{tabular}

Note. PSWQ $=$ Penn State Worry Questionnaire, GDS = Geriatric Depression Scale, DS-B = Digit Span-Backwards, Gender 1= Female, $2=$ Male. $(N=128, * p<.05, * * p<.01)$

Next, results of analyses indicated that the moderation model tested (See, Figure 1) had less than (controlling for age, sex, and years of education) acceptable fit to the data $X^{2}(21, N=128)=3.03, p<.001, \mathrm{CFI}=.71, \mathrm{GFI}=.91, \mathrm{RMSEA}=.13$, and $\mathrm{SRMR}=.10$. A constraint between sex and PSWQ, and between education and DS-B scores were added based on the modification indices with the purpose of improving model fit. The final model had a good fit to the data, $X^{2}(18, N=128)=1.40, p=.113, \mathrm{CFI}=.95$, GFI $=.96, \mathrm{RMSEA}=.06$, and $\mathrm{SRMR}=.07$, and the modifications led to a significant improvement in model fit $\left[X^{2} \Delta=38.43, d f=3, p<.001\right]$. A careful examination of the model indicated that WM capacity (as measured by DS-B) $(B=-.16, \beta=-.15, S E=.07$, $p<.05)$ significantly moderated the relationship of worry with geriatric depression, partially supporting $\mathrm{H} 2$. However, the interaction between inhibition capacity (as measured by Stroop test) and both worry $(B=-.13, \beta=-.12, S E=.06, p=.07)$, and WM performance $(B=.05, \beta=.05, S E=.07, p=.51)$ did not have significant associations with geriatric depression in the elderly population. 


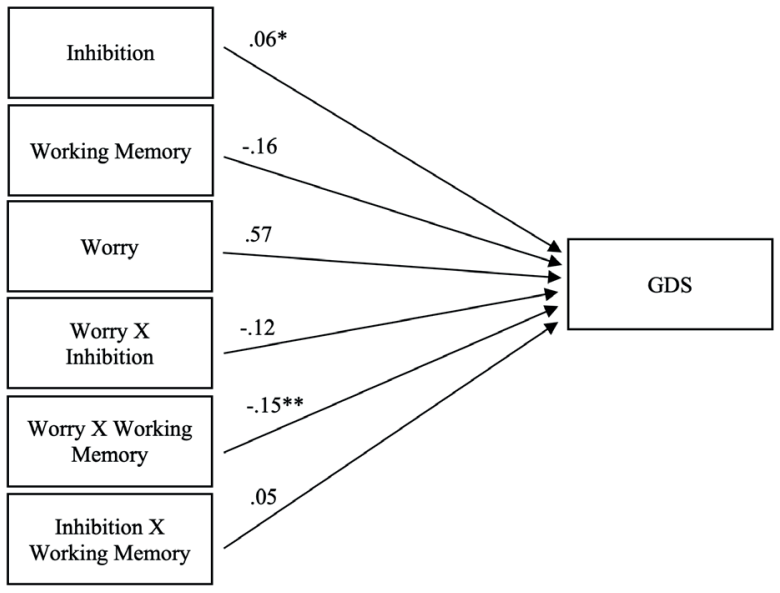

Figure 1. Moderation model demonstrating the interaction between worry and EF (inhibition and working memory) with geriatric depression. $X^{2}(18, N=128)=1.40, p=.113, \mathrm{CFI}=.95$, GFI $=.96$, RMSEA $=.06$, and SRMR $=.07$.

Note. $* p<.05, * * p<.01$.

Probing of the significant interaction between worry and digit span scores was performed using PROCESS (Model 1, Hayes, 2013). Results indicated that the participants DS-B performance was not associated with differences in depression levels among low worriers $(B=.06, S E=.25, t(121)=.09, p=.93,95 \%$ CI -.44 .57). This confirms $\mathrm{H} 1$ for working memory capacity. However, among high worriers, low DS-B performance was significantly associated with higher levels of depression $(B=-.83 S E=$ $.32, t(121)=-2.21, p<.05,95 \% \mathrm{CI}-1.46-.21)(\mathrm{H} 2)$. This result indicates that high WM capacity as measured by the DS-B may be able to buffer the negative impact of worry and thus is associated with lower levels of depression in older adults (See Figure 2). Both $\mathrm{H} 1$ and $\mathrm{H} 2$ were confirmed for working memory capacity, but not for inhibition.

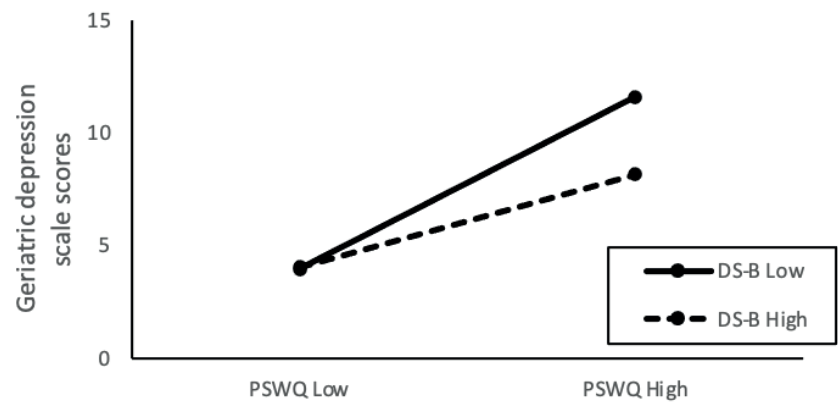

Figure 2. The interactive effect of digit span - backwards (DS-B) and worry on depression scores (DS-B = Digit Span- Backwards, PSWQ = Penn State Worry Questionnaire). 


\section{DISCUSSION}

The current study was aimed at testing the moderator roles of different dimensions of EF (inhibition and WM) in the relationship between RNT (as measured by worry) and depression in a group of older adults. Although the results were not significant for inhibition, a significant moderating effect of WM on the association between RNT and depression was observed. That is, WM capacity did not appear to be responsible for any changes in depression in the individuals with low levels of RNT (H1 for WM capacity). However, in the case of high RNT, higher WM capacity appeared to be able to buffer the negative effect of RNT and thus associated with lower depression scores (H2 for WM capacity). Older adults may use higher levels of WM capacity to manipulate the negative content of worry and perhaps reduce the duration of worry episodes, which in the long run may prevent the individual from developing symptoms of geriatric depression. On the other hand, older adults who have poor WM capacity and are prone to experience RNT may be particularly vulnerable for the development and persistence of depressive symptoms. The current results are in line with the findings of Stout, Shackman, Johnson, and Larson (2015) and Sari, Koster, and Derekshan (2017) who argued that high levels of worry impair the efficiency of WM and individual's capacity for filtering the threatening contents of WM. They also argued that impairments in this capacity lead to a competition between threat related information and task relevant thoughts which contributes to further worry and cognitive impairment. Similarly, Hayes, Hirsch, and Matthews (2008) also indicated a similar relationship between worry and WM deficits which can be responsible for significant increases in the levels of anxiety and depression. Likewise, in an extensive meta-analysis and narrative review, Moran (2016) determined that anxiety, particularly worry, predicts impaired performance on the tasks measuring WM capacity. He suggests a possible cyclical relationship between worry and WM capacity. That is low WM capacity predisposes an individual for anxiety which further impairs WM capacity (Moran, 2016). Furthermore, the current results are also consistent with Alexopoulos' (2003) depressive-executive dysfunction syndrome. However, his model is based on older adults with late-onset-depression whereas in the current study this aspect of participants' depression was not specifically evaluated. So, it cannot be determined if the same predictions hold true for the current sample of older adults.

In the current study, contrary to $\mathrm{H} 2$, the same moderator effect of inhibition on the relationship between RNT and depression was not observed, which may be explained 
by the characteristics of the Stroop task that was used to assess inhibition capacity. Notably, Friedman and Miyake (2004) identified two mechanisms of inhibition, namely Prepotent Response Inhibition (refers to the ability to voluntarily suppress prepotent response), and Resistance to Distractor Interference (refers to the ability to resist the interference of external distractors that are not relevant to the task at hand). They suggested that the Stroop task is a better measure of the former component. It is possible that this component is intact in older adults, an idea which requires further investigation. Lack of significant associations between inhibition, worry and depression might be also related with this sample being a non-clinical sample where depression scores were relatively lower as compared with clinical populations. Furthermore, participants from the current study were either living independently or with their relatives in the community as opposed to nursing homes or assisted living residents. This might have explained the characteristics of the study participants who did not exhibit severe depression and/or cognitive impairment. Research indicated that elderly individuals living in nursing homes scored higher on depression measures compared to their counterparts living at home (Karakaya, Bilgin, Ekici, Köse, \& Otman, 2009; Kerem, Meriç, Kırd1, \& Cavlak, 2001) There is also evidence for high rates of depression and dementia among elderly individuals who live in nursing homes (Şahin ve Yalçın, 2003). Therefore, future research should include participants from nursing homes/assisted living residents to assess these differences.

In contrast with previous findings, significant results indicating a direct link between WM and depression or WM and RNT was not found in the current study. This may originate from the nature of the EF tasks used in the present study. Both, DS-B and Stroop are cool EF tasks that focus on assessment of EF performance with an emotionally neutral stimulus, which at the same time jeopardizes the ecological validity of these measures. More valid results may be obtained in the case of utilizing hot EF tasks that also take the impact of emotional stimuli into account. Studies that utilize hot tasks with mood inductions usually report positive associations between poor WM/updating performance and worry (e.g., Sari et al., 2017). In short, lack of more significant results may stem from not using hot EF tasks which take the impact of emotional arousal into account. Future studies are needed to test the same predictions utilizing EF measures with emotional stimuli. Next, the majority of research on the connection between RNT and depression highlights the important role of shifting capacity. This mechanism had 
been elaborately discussed by Koster et al., (2011) as a factor that generates depression. However, different from the current study, Koster et al. (2011) suggested the cognitive flexibility/shifting aspect of EF as the chief mechanism that is responsible for pathological levels of RNT and depression. The current study could not test the same hypothesis in this sample of older adults, which constitutes another weakness.

In addition to these, the results from the current study have to be interpreted with caution due to the small effect size, which can be due to the use of a non-clinical sample that does not include depression and PSWQ scores that are indicative of a severe pathology. The current study has another limitation due to its cross-sectional and correlational design, which makes it impossible to draw causal interpretations regarding the association between RNT and depression as moderated by WM deficits. Next, despite its significant association with depression in both clinical and non-clinical groups (Segerstrom et al., 2000), use of worry instead of rumination may also be considered as a limitation of the current study. Another limitation is the lack of a comparison group composed of younger participants. Future research needs to focus on research designs that can possibly overcome these limitations. It will be also important to examine different EF components using multiple measures as suggested by Miyake et al. (2000). Moreover, the experience sampling method (ESM) can be utilized to collect more accurate data regarding the momentary changes experienced in the RNT levels.

In conclusion, the present study tested the moderator roles of different dimensions of EF on the relationship between RNT and geriatric depression, providing evidence for a significant predictive role of WM- RNT interaction on the experience of depression in older adults. Overall, the findings regarding the lower WM capacity and RNT as interacting risk factors for depression in older adults has significant clinical implications for prevention and intervention programs. It seems important to address both executive dysfunction and worry when assessing and providing treatment for older patients who present with depression. Identification of and development of compensatory treatments for executive dysfunction in older patients may help to improve overall outcome of the treatments and increase medication adherence (Lockwood et al., 2002).

The present results underline the need to study geriatric depression in its own context as risk and maintaining factors maybe different in comparison with other age groups. It would help psychologists greatly if these factors are also investigated in clinical 
populations to see whether similar results will replicate. Understanding moderator factors can enhance clinical interventions and widen the opportunities to better the lives of elderly individuals. It is hoped that the results from this study guide future research investigating clinical interventions targeting to reduce RNT patterns as well as models that enhance working memory capacity in geriatric patients in order to reduce depressive symptoms.

Acknowledgment: We thank Yeditepe University undergraduate students who were involved in data collection.

Peer-review: Externally peer-reviewed.

Conflict of Interest: The authors have no conflict of interest to declare.

Grant Support: The authors declared that this study has received no financial support.

Hakem Değerlendirmesi: Dış bağımsız.

Çıkar Çatışması: Yazarlar çıkar çatışması bildirmemiştir.

Finansal Destek: Yazarlar bu çalışma için finansal destek almadığını beyan etmiştir.

\section{References/Kaynakça}

Alexopoulos, G. S. (2003). The role of executive function in late-life depression. The Journal of Clinical Psychiatry, 64(14), 18-23.

Alexopoulos, G. S., Borson, S., Cuthberth, B. N., Devanand, D. P., Mulsant, B. H., Olin, J. T., \& Oslin, D. W. (2002). Assessment of late life depression. Biological Psychiatry, 52(3), 164-174. https://doi. org/10.1016/S0006-3223(02)01381-1

Alexopoulos, G. S., Bruce, M. S., \& Hull, J. (1999). Clinical determinants of suicidal ideation and behavior in geriatric depression. Archives of General Psychiatry, 56(11). 1048-1053. doi:10.1001/ archpsyc.56.11.1048

Alexopoulos, G. S., Kiosses, D. N., Heo, M., Murphy, C. M., Shanmugham, B., \& Gunning-Dixon, F. (2005). Executive dysfunction and the course of geriatric depression. Biological Psychiatry, 58(3), 204-210. https://doi.org/10.1016/j.biopsych.2005.04.024

Alexopoulos, G. S., Meyers, B. S., Young, R. C., Kalayam, B., Kakuma, T., Gabrielle, M., ... Hull, J. (2000). Executive dysfunction and long-term outcomes of geriatric depression. Archives of General Psychiatry, 57(3), 285-290. doi:10.1001/archpsyc.57.3.285

Bentler, P. M. (1990). Comparative fit indexes in structural models. Psychological Bulletin, 107(2), 238-246. http://dx.doi.org/10.1037/0033-2909.107.2.238

Buck, J. M., Kelly, W. E., \& Silver, N. C. (2008). An investigation of the relationship between depression and worry: A research note. Individual Differences Research, 6(2), 120-122.

Byrne, B. M. (2016). Structural equation modeling with AMOS: Basic concepts, applications, and programming. New York: Routledge.

Conwell, Y., Duberstein, P. R., \& Caine, E. D. (2002). Risk factors for suicide in later life. Biological Psychiatry, 52(3), 193-204. https://doi.org/10.1016/S0006-3223(02)01347-1

Diamond, A. (2013). Executive functions. Annual Review of Psychology, 64, 135-168. https://doi. org/10.1146/annurev-psych-113011-143750 
Doraiswamy, P. M., Khan, Z. M., Donahue, R. M. J., \& Richard, N. E. (2002). The spectrum of qualityof-life impairments in recurrent geriatric depression. The Journals of Gerontology: Series A, 57(2), M134-M137. https://doi.org/10.1093/gerona/57.2.M134

Ehring, T., \& Watkins, E. R. (2008). Repetitive negative thinking as a transdiagnostic process. International Journal of Cognitive Therapy, 1(3), 192-205. https://doi.org/10.1521/ijct.2008.1.3.192

Ertan, T., \& Eker, E. (2000). Reliability, validity and factor structure of the geriatric depression scale in Turkish elderly: Are there different factor structures for different cultures? International Psychogeriatrics, 12(2), 163-162. https://doi.org/10.1017/S1041610200006293

Ertan, T., Eker, E., Güngen, C., Engin, F., Yaşar, R., \& Kılıç, G., \& Özel, S. (1999, August). The standardized mini mental state examination for illiterate Turkish elderly population. Paper presented at the 2nd International Symposium on Neurophysiological and Neuropsychological Assessment of Mental and Behavioral Disorders, Bursa, Turkey.

Ertan, T., Eker, E., \& Şar, V. (1997). Reliability and validity of the geriatric depression scale in Turkish elderly population. Archives of Neuropsychiatry (Turkish), 34(1), 62-71.

Fischer, C., Schweizer, T. A., Atkins, J. H., Bozanovic, R., Norris, M., Herrmann, N., ... Rourke, S. B. (2008). Neurocognitive profiles in older adults with and without major depression. International Journal of Geriatric Psychiatry, 23, 851-856. https://doi.org/10.1002/gps.1994

Fiske, A., Wetherell, J. L., \& Gatz, M. (2009). Depression in older adults. Annual Review of Clinical Psychology, 5, 363-389. https://doi.org/10.1146/annurev.clinpsy.032408.153621

Friedman, N. P., \& Miyake, A. (2004). The relations between inhibition and interference control functions: A latent-variable analysis. Journal of Experimental Psychology: General, 133(1), 101135. doi: 10.1037/0096-3445.133.1.101

Friedman, N. P., \& Miyake, A. (2017). Unity and diversity of executive functions: Individual differences as a window on cognitive structure. Cortex, 86, 186-204. https://doi.org/10.1016/j. cortex.2016.04.023

Gathercole, S. E. (1994). Neuropsychology and working memory: A review. Neuropsychology, 8(4), 494-505.

Gazzaley, A., Cooney, J. W., Rissman, J., \& D’Esposito, R. (2005). Top-down suppression deficit underlies working memory impairment in normal aging. Nature Neuroscience, 8, 1298-1300. doi: $10.1038 / \mathrm{nn} 1543$

Golden, C. J. (1978). Stroop Color and Word Test. A Manual for Clinical and Experimental Uses. Illinois: Stoelting Company.

Güngen, C., Ertan, T., Eker, E., Yaşar, R., \& Engin, F. (2002). Reliability and validity of the standardized Mini Mental State Examination in the diagnosis of mild dementia in Turkish population. Turkish Journal of Psychiatry (Turkish), 13(4), 273-281.

Hasher, L., Quig, M. B., \& May, C. P. (1997). Inhibitory control over no-longer-relevant information: Adult age differences. Memory \& Cognition, 25(3), 286-295. https://doi.org/10.3758/BF03211284

Hayes, A.F. (2013). Introduction to mediation, moderation, and conditional process analysis: A regression-based approach. New York: The Guilford Press.

Hayes, S., Hirsch, C., \& Matthews, A. (2008). Restriction of working memory capacity during worry. Journal of Abnormal Psychology, 117(3), 712-717. http://dx.doi.org/10.1037/a0012908

Hu, L., \& Bentler, P. M. (1999). Cutoff criteria for fit indexes in covariance structure analysis: Conventional criteria versus new alternatives. Structural Equation Modeling, 6(1), 1-55. https:// doi.org/10.1080/10705519909540118 
Hu, L., Bentler, P. M., \& Kano, Y. (1992). Can test statistics in covariance structure analysis be trusted? Psychological Bulletin, 112(2), 351-362.

Hubbard, N. A., Hutchison, J. L., Hambrick, D. Z., \& Rypma, B. (2016). The enduring effects of depressive thoughts on working memory. Journal of Affective Disorders, 190, 208-213. https://doi. org/10.1080/02699931.2014.991694

Joormann, J., \& Gotlib, I. H. (2010). Emotion regulation in depression: relation to cognitive inhibition. Cognition and Emotion, 24(2), 281-298. https://doi.org/10.1080/02699930903407948

Joormann, J., Siemer, M., \& Gotlib, I. H. (2007). Mood regulation in depression: Differential effects of distraction and recall of happy memories on sad mood. Journal of Abnormal Psychology, 116, 484-490. doi:10.1037/0021-843X.116.3.484

Kalayam, B., \& Alexopoulos, G. S. (1999). Prefrontal dysfunction and treatment response in geriatric depression. Archives of General Psychiatry, 56(8), 713-718. doi:10.1001/archpsyc.56.8.713

Karakaya, M. G., Bilgin, S. Ç., Ekici, G., Köse, N., \& Otman, A. S. (2009). Functional mobility, depressive symptoms, level of independence, and quality of life of the elderly living at home and in the nursing home. Journal of the American Medical Directors Association, 10(9), 662-666. doi. org/10.1016/j.jamda.2009.06.002

Kerem, M., Meriç, A., Kırd1, N., \& Cavlak, U. (2001). Evaluation of elderly living at home and rest house. Turkish Journal of Geriatrics, 4(3), 106-112.

Kline, R. B. (1998). Principles and practices of structural equation modeling. New York: Guilford.

Koster, E. H., De Lissnyder, E., Derakshan, N., \& De Raedt, R. (2011). Understanding depressive rumination from a cognitive science perspective: The impaired disengagement hypothesis. Clinical Psychology Review, 31(1), 138-145. https://doi.org/10.1016/j.cpr.2010.08.005

Lockwood, K. A., Alexopoulos, G. S., \& van Gorp, W. G. (2002). Executive dysfunction in geriatric depression. American Journal of Psychiatry, 159(7), 1119-1126. https://doi.org/10.1176/appi. ajp.159.7.1119

Luppa, M., Sikorski, C., Luck, T., Ehreke, L., Konnopka, A., Wiese, B., ... Riedel-Heller, S. G. (2012). Age- and gender-specific prevalence of depression in latest-life - Systematic review and metaanalysis. Journal of Affective Disorders, 136(3), 212-221. https://doi.org/10.1016/j.jad.2010.11.033

Meyer, T. J., Miller, M. L., Metzger, R. L., \& Borkovec, T. D. (1990). Development and validation of the Penn State Worry Questionnaire. Behavior Research and Therapy, 28(6), 487-495. https://doi. org/10.1016/0005-7967(90)90135-6

Miyake, A., Friedman, N. P., Emerson, M. J., Witzki, A. H., Howerter, A., \& Wager, T. D. (2000). The unity and diversity of executive functions and their contributions to complex "frontal lobe" tasks: A latent variable analysis. Cognitive Psychology, 41(1), 49-100. https://doi.org/10.1006/ cogp.1999.0734

Moran, T. P. (2016). Anxiety and working memory capacity: A meta-analysis and narrative review. Psychological Bulletin, 142(8), 831. http://dx.doi.org/10.1037/bul0000051

Nebes, R. D., Butters, M. A., Mulsant, B. H., Pollock, B. G., Zmuda, M. D., Houck, P. R., \& Reynolds, C. F. (2000). Decreased working memory and processing speed mediate cognitive impairment in geriatric depression. Psychological Medicine, 30(3), 679-691.

Nolen-Hoeksema, S. (2000). The role of rumination in depressive disorder and mixed anxiety/depressive symptoms. Journal of Abnormal Psychology, 109, 504-511. doi: 101037/10021-843X.109.3.504

Pe, M. L., Raes, F., \& Kuppens, P. (2013). The cognitive building blocks of emotion regulation: ability to update working memory moderates the efficacy of rumination and reappraisal on emotion. PLOS one, 8(7), e69071. https://doi.org/10.1371/journal.pone.0069071 
Philippot, P., \& Agrigoroaei, S. (2017). Repetitive thinking, executive functioning, and depressive mood in the elderly. Aging \& Mental Health, 21(11), 1192-1196. https://doi.org/10.1080/136078 63.2016.1211619

Samtani, S., \& Moulds, M. N. (2017). Assessing maladaptive repetitive thought in clinical disorders: A critical review of existing measures. Clinical Psychology Review, 53, 14-28. https://doi. org/10.1016/j.cpr.2017.01.007

Sari, B. A., Koster, E. H. W., \& Derekshan, N. (2017). The effects of active worrying on working memory capacity. Cognition and Emotion, 31(5), 995-1003. https://doi.org/10.1080/02699931.20 16.1170668

Segerstrom, S. C., Tsao, J. C. I., Alden, L. E., \& Craske, M. E. (2000). Worry and rumination: Repetitive thought as a concomitant predictor of negative mood. Cognitive Therapy and Research, 24(6), 671688. https://doi.org/10.1023/A:1005587311498

Sezgin, N., Baştuğ, G., Yargıc1-Karaağaç, S., \& Yılmaz, B. (2014). Turkish Standardization of Wechsler Adult Intelligence Scale-Revised (WAIS-R): Pilot Study. Ankara Üniversites, Dil ve Tarih-Coğrafya Fakültesi Dergisi (Turkish), 54(1), 451-480.

Stout, D. M., Shackman, A. J., Johnson, J. S., \& Larson, C. L. (2015). Worry is associated with impaired gating of threat from working memory. Emotion, 15(1), 6-11. doi: 10.1037/emo0000015

Stroop, J. R. (1935). Studies of interference in serial verbal reactions. Journal of Experimental Psychology, 18(6), 643-662.

Snyder, H. R. (2013). Major depressive disorder is associated with broad impairments on neuropsychological measures of executive function: a meta-analysis and review. Psychological Bulletin, 139(1), 81. doi: 10.1037/a0028727

Şahin, E. M., \& Yalçın, B. M. (2003). Comparing the incidence of depression at the elderly living in nursing home or at their own homes. Turkish Journal of Geriatrics, 6(1), 10-13.

von Hippel, W., Vasey, M. W., Gonda, T., \& Stern, T. (2008). Executive function deficits, rumination, and late-onset depressive symptoms in older adults. Cognitive Therapy and Research, 32(4), 474487. https://doi.org/10.1007/s10608-006-9034-9

Watkins, E. R. (2016). Rumination-focused cognitive-behavioral therapy for depression. New York: Guilford Press.

Wechsler, D. (1981). Wechsler Adult Intelligence Scale-Revised Manual. New York: Psychological Corporation.

West, R. \& Alain, C. (2000). Age-related decline in inhibitory control contributes to the increased Stroop effect observed in older adults. Psychophysiology, 37(2), 179-189. https://doi.org/10.1111/14698986.3720179

Wuthrich, V. M., Johnco, C., \& Knight, A. (2014). Comparison of the Penn State Worry Scale (PSWS) and abbreviated version (PSWS-A) in a clinical and non-clinical populations of older adults. Journal of Anxiety Disorders, 28, 657-663. https://doi.org/10.1016/j.janxdis.2014.07.005

Yesavage, J. A., Brink, T. L., Rose, T. L., Lum, O., Huang, V., Adey, M., \& Leirer, V. O. (1983). Development and validation of a Geriatric Depression Scale: A preliminary report. Journal of Psychiatric Research, 17(1), 37-49. https://doi.org/10.1016/0022-3956(82)90033-4

Yılmaz, A. E., Gençöz, T., \& Wells, A. (2008). Psychometric characteristics of the Penn State Worry Questionnaire and Metacognitions Questionnaire-30 and metacognitive predictors of worry and obsessive-compulsive symptoms in a Turkish sample. Clinical Psychology and Psychotherapy, 15(6), 424-439. https://doi.org/10.1002/cpp.589 